\title{
Syngas Underground Coal Gasification (UCG) Testing of In-Situ Type Lignite Coal and Fracture Type Coal
}

\author{
Julismi $^{1}$, Rusdianasari ${ }^{2}$, Abu Hasan ${ }^{2}$ \\ ${ }^{1}$ Applied Master of Renewable Energy Engineering, Politeknik Negeri Sriwijaya, Palembang, Indonesia \\ ${ }^{1}$ PT Satria Bahana Sarana, Jalan Jurang Parigi Dalam No 5, Tanjung Enim Indonesia \\ ${ }^{2}$ Chemical Engineering Department, Renewable Energy Study Program, \\ Politeknik Negeri Sriwijaya, Palembang, Indonesia
}

\begin{tabular}{l} 
Article Info \\
\hline Article history: \\
Received July 11, 2021 \\
Revised August 10, 2021 \\
Accepted August 20, 2021 \\
\hline
\end{tabular}

Keywords:

Renewable energy

Underground coal gasification

Syngas

Lignite coal

Fracture type coal

\begin{abstract}
The advancement and utilization of technology require energy, namely electricity and fuel energy. The increasing cost of fossil energy, the scarcity of non-renewable energy sources and the increasing energy demand requires diversification of energy resources. One of the new renewable energy sources currently being developed in Indonesia is Underground Coal Gasification (UCG). UCG is a new technology that utilizes unmined coal. In the UCG process, coal is burned underground and the syngas produced is collected through bore wells for processing or direct use. The resulting syngas is analyzed to see the effect of in-situ type of lignite coal and fractured type of coal on syngas production using the UCG method. Tests carried out on fracture-type lignite coal for 120 minutes with a sample weight of $1.3 \mathrm{~kg}$ obtained a $\mathrm{CH}_{4}$ gas concentration of $0.24 \%$, which is relatively low compared to the insitu type lignite coal sample $\mathrm{CH}_{4}$ gas concentration of $1.13 \%$. The $\mathrm{CO}_{2}$ concentration was $54.46 \%$ in the fracture sample, and the In-Situ type sample was $52.19 \%$. The $\mathrm{O}_{2}$ content with a value of $19.43 \%$ for the Fracture Type sample and $4.94 \%$ for the In-Situ type sample. Fracture Type and In-situ Lignite Coal produced fewer syngas products due to UCG testing than high-rank coals such as subbituminous and bituminous coal.
\end{abstract}

This is an open access article under the CC BY-SA license.

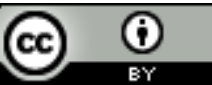

\section{Corresponding Author:}

Rusdianasari

Chemical Engineering Department, Renewable Energy Study Program,

Politeknik Negeri Sriwijaya, Palembang, Indonesia

Email: rusdianasari@polsri.ac.id

\section{INTRODUCTION}

Energy has a vital role in human life, where every day man uses energy to do his life activities. The increasing number of human populations causes the energy demands also to increase to achieve living standards. Moreover, the increasing energy demand and the acceleration of development in the government's social, economic, and technological developments face the challenges of limited available energy sources. 
The advancement and utilization of technology require energy, namely electricity and fuel energy. The increasing cost of fossil energy, the scarcity of renewable energy sources, and the increasing energy demand require diversification of energy resources. The search for renewable alternative energy and its use is intensified to ensure the availability of energy,

In overcoming limited energy sources, Indonesia is making efforts to use renewable energy that can be renewed by accelerating the realization of the energy mix (energy mixed) in 2025, with the role of new and renewable energy is at least $23 \%$. In 2050 it will increase by $31 \%$ throughout its economy fulfilled as set out in the national energy management blueprint [1][28][29].

Such efforts to increase the renewable energy mix of all elements, both central government, local government, private parties, and industry to the community, is one of the options to meet future energy needs so that it does not rely entirely on fossil energy sources. Indonesia's renewable energy potential, based on the Ministry of Energy and Mineral Resources, reaches $443 \mathrm{GW}$, Most of which almost 50\% comes from solar energy [21]-[27], the next water energy (20\%), and wind (14\%) [2]-[4][30]. Although it is based only on solar energy and clean and unlimited energy sources, this solution has several problems in daily life that must be considered. The problem is related to resources, limited potential, basic load, grids, and primary resources.

When reviewed from resources, coal is one of the possible energy sources to be developed today. However, it is also worth considering the environmental problems that are the main obstacles when using conventional technology, both during the mining process and processing. One possible solution is to use nonconventional underground coal gasification (UCG) technology that directly creates gas by burning coal insitu underground. This method is considered environmentally friendly because there is no need to exploit coal and when the gasification process does not produce harmful gases such as $\mathrm{SO}_{2}$ and NOx. Although this technology has been proven in some countries, this technology needs more in-depth research if it wants to be developed in Indonesia because it is highly dependent on local geological and lithological conditions. Therefore, the evaluation of geological, hydrogeological, geochemical, and geomechanical conditions in Indonesia needs to be considered to see the suitability of the selection of the UCG method or technology [3].

Coal is one of the most significant alternative energy sources in Indonesia. According to the Geological Agency, the amount of coal resources is about 161 billion tons and if exploited at the current production level, it is expected to reach between years. The 120 billion tons of coal can be mined open pit and the rest using underground mining methods (40.3 billion tons). The potential will be even more significant when calculated to a depth of $1000 \mathrm{~m}$ above sea level [5][15]-[20]. In 2018, Indonesia's total primary energy production consisting of petroleum, natural gas, coal, and renewable energy reached 411.6 MTOE. $64 \%$ or 261.4 MTOE of the total production is exported, mainly coal and LNG. In addition, Indonesia also imports energy, mainly crude oil and fuel products amounting to 43.2 MTOE and a small amount of high-calorie coal needed to meet the needs of the industrial sector.

However, in the use of coal, the government is concerned about pollution caused by burning coal and environmental damage related to mining. Therefore, this potential needs to be developed with environmentally friendly technology, one of which is underground coal gasification (UCG). This technology has the potential to be developed in Indonesia because, in addition to being known as clean energy, technologies are also following the characteristics of Indonesian coal, which is generally low quality. In addition to intensifying the use of coal at unfavorable depths for open and underground mines, low-ranking coal utilization is also an alternative to fossil energy derived from oil and gas (oil and gas).

Underground Coal Gasification (UCG) is a new technology that utilizes unmined coal. In the UCG process, coal is burned underground. The resulting syngas is collected through drill wells for direct processing or use. UCG is an alternative to exploiting chemical energy from in situ coal reserves. UCG is similar to surface coal gasification techniques where coal, with the help of oxidation, is dried by pyrolyzed process burned [6-8].

Researchers conducted tests on gas products or called syngas, which was produced to determine insitu type coal and coal type fractures against syngas production if using the Underground Coal Gasification (UCG) method, which is accommodated in Tedlar gas sampling bags. The concentration analysis of the gas content of the product, syngas, is distinguished by the influence of coal ratings and combustion temperatures in the laboratory. UCG research with laboratory-scale prototypes is expected to be a crucial first step towards coal utilization, especially low-ranking coal [9].

Lignite or coal-brown is a newly formed type of young coal. It is said that young coal because lignite is the first form of coalifaction process from peat to coal. According to research, lignite was formed 251 million years ago. Alternatively, in other words, the material that forms comes from the Mesozoic and Cenozoic epochs. The characteristics of lignite include brown color, has little energy (about $10-20 \mathrm{MJ} / \mathrm{Kg}$ ), has many impurities (up to 40 - 75\% impurities), carbon element content is only 60 to $70 \%$ contains about 9 $19 \%$ dust. Due to its very low efficiency, lignite is not widely marketed for transportation or industrial needs. Lignite is usually used as fuel for power plants [10]. 
Lignite coal is required in-situ and in the form of fractures to conduct this UCG research. Ins-situ coal is a condition of coal that is still intact in the coal seam. Fractured coal has a varying size because the assumption is that this fractured coal is underground coal that was detonated at the beginning before gasification, then the size is irregular [11-12].

In the process, the coal under the ground reacts with air or oxygen, and water vapor injected to form gases, liquids, and ash as residues. Injected components will react with coal to form combustion gas brought to the surface through gas production wells. The gas is then cleaned through a filtering process and used as fuel or chemical raw material. The gas produced was a mixture of combustion gas (carbon monoxide, hydrogen, and methane) and unburned gas (carbon dioxide, nitrogen, and water vapor), and Si [13-14].

\section{RESEARCH METHOD}

\subsection{Research Location}

This study took place in Tanjung Enim, a city famous for its coal products located in South Sumatra. Coal extraction site at Muara Tiga Besar (MTB) mine at coordinate point x: 356573 y: 9588585 or at a coordinate point of 3043'16.315"LS, 103042'30.463"BT. The average temperature in Tanjung Enim is between $22^{\circ}-33^{\circ} \mathrm{C}$, with average sunlight radiation of $45 \%$, high humidity, and wind speed between 2.3 $\mathrm{km} / \mathrm{h}-4.5 \mathrm{~km} / \mathrm{h}$ [11]. The coal used in this test was obtained from coal extraction location at Muara Tiga Besar (MTB) mine at coordinate point x: 356573 y: 9588585 or at a coordinate point of $3^{\circ} 43^{\prime} 16.315^{\prime \prime} L S$, $103^{\circ} 42^{\prime} 30.463^{\prime \prime} B T$ on Figure 1.

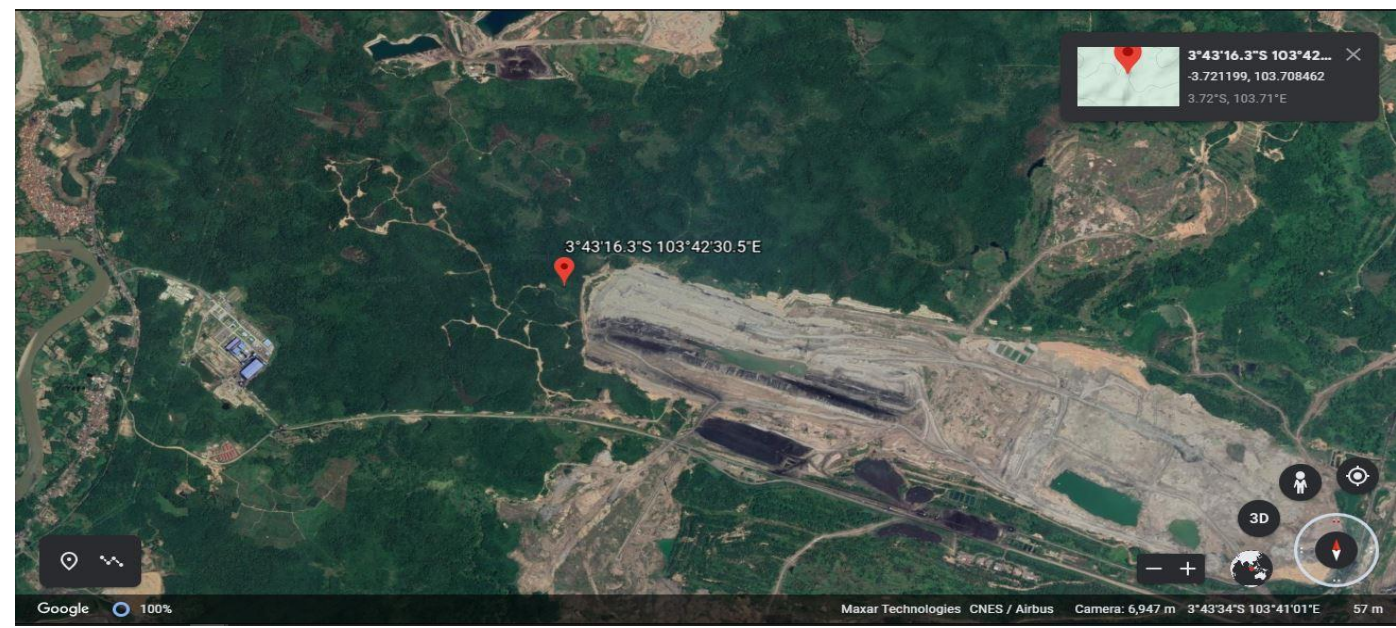

Figure 1. Coal Sampling Location

\subsection{Coal Sampling Technique}

Classification of Coal used as a sample of coal to be studied, using lignite coal with calories 4700 with mine brand PTBA MT 47 (4600 - $4800 \mathrm{kcal} / \mathrm{kg}$, ar). This coal sample was taken at coordinate point x: 356573 y: 9588585 or at a coordinate point of $3^{\circ} 45^{\prime} 52.189^{\prime \prime L S}, 103^{\circ} 46^{\prime} 18.494 " \mathrm{E}$.

\subsubsection{Sampling Location}

The location of the coal sampling can be seen in Figure 1. Coal Sampling Process. The representative part of the material body (coal) for the test/analysis is used to determine the characteristics of the original material. Taken by the correct/appropriate method and protected against contamination/alteration. The coal extraction was conducted directly by researchers and accompanied by a PT Laya Water Coal Mining task force team. Bukit Asam is directly on coal mining. The first and second coal samples were taken at the Muara Tiga Besar Utama mine site.

\subsubsection{In-Situ Type Coal}

In-situ is the condition of coal that is still intact in the coal seam. In coal, samples that have been taken from the front will be formed following the dimensions of the gasification combustion chamber, namely the length of $18 \mathrm{~cm}$ and diameter of $13.5 \mathrm{~cm}$. The aim is to give an overview of the prototype model UCG coal condition at the time of the layer below the ground. 


\subsubsection{Fracture-Type Coal}

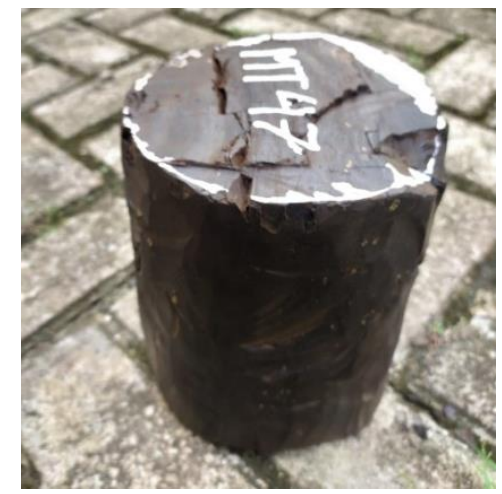

Figure 2. In-Situ Type MT 47 Coal

Fracture is where the condition of coal in the underground layer has undergone breaking or melting process to create cavities in the coal seam. In this UCG prototype model, it is assumed to be the same as that.

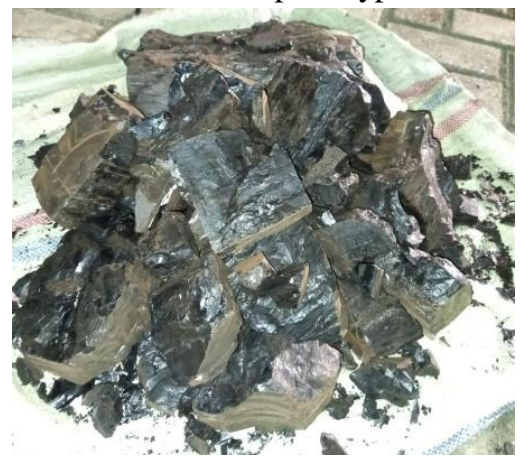

Gambar 3. Fracture-Type MT 47 Coal

\subsection{UCG Prototype}

As shown in figure 4, the injection in the UCG prototype is water, nitrogen, and oxygen, for the air tubes provided (Nos. 1 and No. 2). Each air tube used as an injection will be controlled by a regulator (No. 4). Moreover, the prototype output is two lanes where the first line for the burn test and the second for the syngas reservoir are produced. The initial combustion or starting point here uses a glow plug with a specification of 24 volts and 20 Ampere (No. 16).

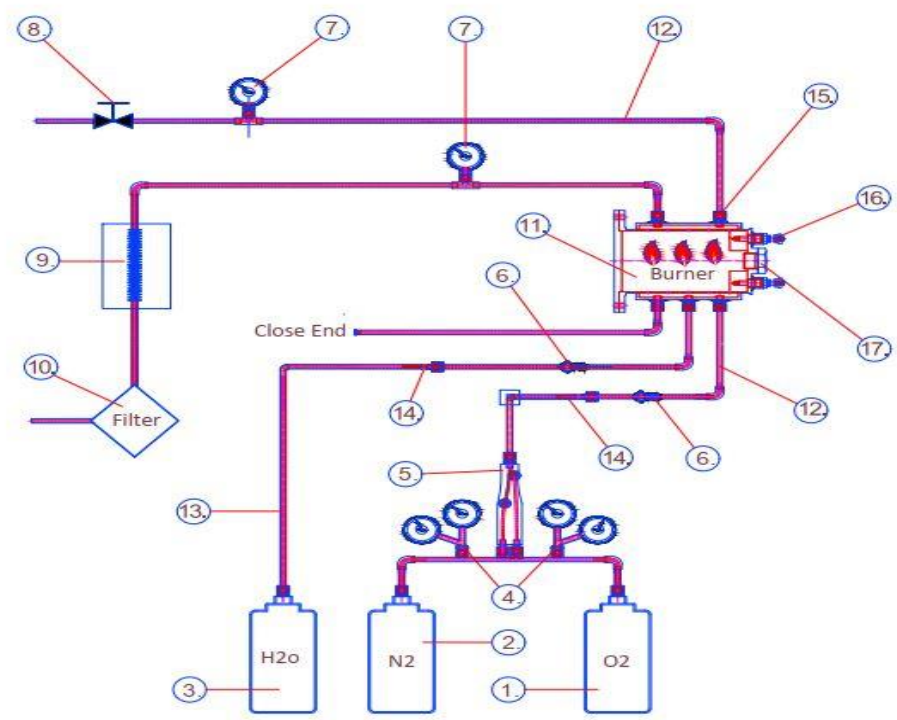

Figure 4. Underground Coal Gasification Prototype Design

Table 1. Description of the Underground Coal Gasification Prototype Design Drawing 


\begin{tabular}{clll}
\hline No & \multicolumn{1}{c}{ Keterangan } & No & Keterangan \\
\hline 1 & Oxygen Tank & 10 & Filter \\
2 & Nitrogen Tank & 11 & Combustion \\
3 & Air and Steam Tank & 12 & Tube \\
4 & Regulator & 13 & Hose \\
5 & Gun Mixer & 14 & Conector Hose \\
6 & Check Valve & 15 & Conector Tube \\
7 & Pressure Gauge & 16 & Glow Plug \\
8 & Gate Valve & 17 & Plug \\
9 & Cooler & & \\
\hline
\end{tabular}

\subsection{Stages of Testing with UCG Prototype}

The testing phases of lignite coal samples sourced from in-situ and non-in-situ locations used in this study include:

- Stage of analysis of ultimate and proximate coal samples.

- This stage is a sampling process conducted in the laboratory of the coal transport handling task force (PAB) PT. Asam Hill,

- Coal burning testing phase (UCG) using UCG prototype conducted at AKIPBA Tanjung Enim

- Syngas testing stage

\subsubsection{Injection Process}

The injection process is done through an injection pipe, which measures $1 / 2$ inch as much as three injection pipes for each injection in the form of gas, Air, Oxygen, and Nitrogen. All three injections will be inserted into the coal seam simultaneously or in the presence of mixing. Then it will go into 2 UCG combustion holes. The percentage amount of each injection is what will be the material when data retrieval. The percentage setting of each injection will use an analog regulator, and each channeling pipe will be given a valve.

In the process, there is an output hole for syngas exit in the form of brass pipes with a diameter of $1 / 2$ inch. The impact of the different percentages of each injection will undoubtedly have different temperature values, which are measured using thermocouples at some point of combustion temperature to describe the spread of gasification. During syngas production, the syngas output pipe will be connected to the container tube. The temperature obtained in the UCG process describes the spread of gasification with the maximum temperature estimated to be measurable in the coal seam at about $1000{ }^{\circ} \mathrm{C}$, with an oxidation zone at a distance of 1 meter from the face of the coal seam. Based on the theory referred to that the main gas components that come out as syngas are $\mathrm{H}_{2}, \mathrm{CO}, \mathrm{CH}_{4}$, and $\mathrm{CO}_{2}$, which can be used directly for electrical and heat production or as raw materials for chemical synthesis (syngas)[18][ 19].

\subsection{Coal Sampling Test}

\subsubsection{Proximate Analysis}

Proximate analysis showed the percent of the weight of fixed carbon, volatile materials, ash, and moisture content in coal. The amount of fixed carbon and volatile materials directly contributes to the heat value of coal. Fixed carbon acts as the primary heat generator during combustion, while the high content of volatile materials indicates the ease of ignition of fuel. Ash content is important in the design of furnace grate, combustion volume, pollution control equipment, and system handling of ash in furnaces.

Lignite coal samples, included in Brown Coal, had total moisture content of $70 \%$ (ash free), equivalent to a caloric value of about $1800 \mathrm{KCa} / \mathrm{kg}$ and the upper limit at a caloric value of $5700 \mathrm{KCa} / \mathrm{kg}$. Based on the treatment of the sample, quality analysis is distinguished in several analytical bases, namely: As received (arb), Dried Water (adb), Dry (db), Dry ash-free (daf), Dry mineral matter-free (dmmf).

Generally, to determine the quality of coal is carried out chemical analysis on coal, which includes proximate analysis and ultimate analysis. Proximate analysis is done to determine the amount of water (moisture), flying substances (volatile matter), solid carbon (fixed carbon), and ash content (ash). In contrast, ultimate analysis is done to determine chemical elements in coal such as carbon, hydrogen, oxygen, nitrogen, sulfur, additional elements, and rare elements. Size (coal size)The size of coal grains is limited to a range of 
fine grains (pulverized coal or dust coal)and coarse grains (lump coal). The finest grains are for a maximum size of 3 millimeters, while the roughest grains are up to 50 millimeters in size.

\subsubsection{Ultimate Analysis}

The ultimate analysis is a laboratory analysis to determine the ash, carbon, hydrogen, oxygen, and sulfur content in coal with specific methods. The content is expressed in percent on the base and the sample is dried at $105{ }^{\circ} \mathrm{C}$ in moisture-free, and ash-free ultimate analysis is performed to determine carbon levels $(\mathrm{C})$, hydrogen $(\mathrm{H})$, oxygen $(\mathrm{O})$, nitrogen, $(\mathrm{N})$, and sulfur $(\mathrm{S})$ in carbon.

\subsection{Underground Coal Gasification Prototype Testing}

Underground Coal Gasification testing conducted has the same principles as those in the field. The testing process is conducted in a confined state to represent the state contained in the earth's surface. As seen in the injection image on the UCG prototype of water, nitrogen, and oxygen, the air tubes that have been provided can be seen in Figure 5 a). Each air tube used as an injection will be controlled with a regulator, as can be seen in Figure $5 \mathrm{~b}$ ). And the prototype output is two lanes where the first line for the burn test and the second for the syngas reservoir produced. Initial combustion or starting point here using glow plug with specification 24 volt and 20 Ampere Figure 5 c).

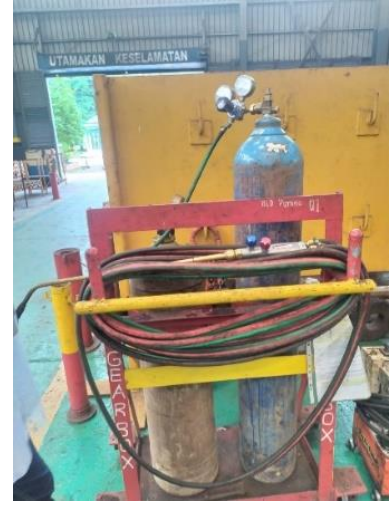

a)

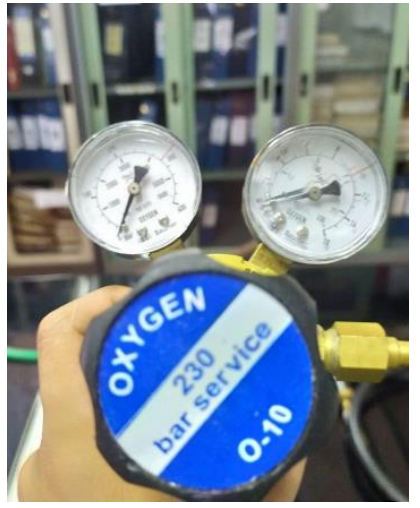

b)

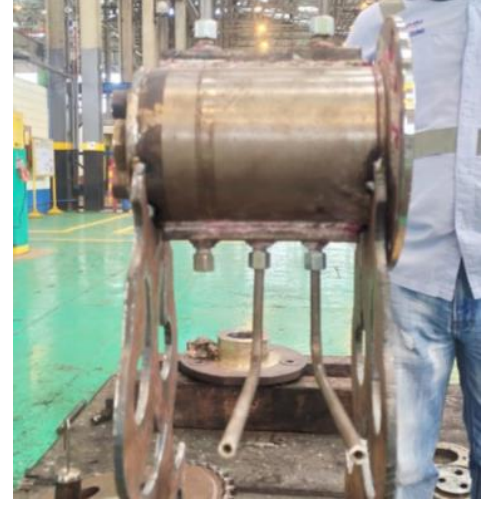

c)

Figure 5. a) Air Tank, b) Oxygen Regulator, dan c) Combustion Chamber

The gas that has been produced with a possible temperature of $800^{\circ} \mathrm{C}$ so that it must be cooled with a cooler can be seen in the picture then passes through the filter as the last filter before being accommodated in the reservoir. This filter functions to filter out water vapor that is not needed in the reservoir. The initial step of the glow plug is heated for the initial ignition of the coal. After combustion occurs, the required injection is injected into the combustion. Shortly after the coal burns the glow plug is turned off. Combustion occurs in the combustion chamber and the temperature can be determined through a thermocouple. If combustion has occurred, syngas is expected to be produced. This can be known through a pressure gauge with a maximum specification of 49 psi. If there is a movement of pressure from the pressure gauge, it is indicated that syngas has been produced. In the pipe connection from injection to combustion, there is a check valve. This tool prevents the injection gas or syngas produced from returning or entering the injection tube, which can be seen in the picture, so this check valve is a safety. On the output pipe of the fuel test, a gate valve is installed. When the fire test is carried out, the gate valve is opened as needed if the end of the pipe exits gas and burns. In this case, syngas has been produced, which can be seen in Figure 14, which will later be captured and accommodated in a container for testing in the laboratory. In laboratory tests, it will be known what content is in the syngas.

\section{RESULTS AND DISCUSSION}

\subsection{MT 47 Sample Coal Characteristics}

Coal quality is the chemical \& physical properties of coal that can affect its potential use. Determined by maceral and mineral content and rank and determined by chemical \& physical analysis of coal. Each type of coal has a different composition. Proximate coal content testing is needed to determine the character and composition of coal, physically, chemically, and fuel properties of the coal that will be used in 
the gasification process. Proximate analysis of the MT 47 coal type shows the moisture, volatile matter, ash and fixed carbon content in the coal. This sampling was carried out in the Coal Transport Handling Unit (PAB) laboratory of PT. Bukit Asam as shown in Table 2.

Table 2. MT 47 Coal Proximate Analysis

\begin{tabular}{lc}
\multicolumn{2}{c}{ Table 2. MT 47 Coal Proximate Analysis } \\
\hline \multicolumn{2}{c}{ Analysis Proximate Batubara MT 47 } \\
\hline Seam & A1 \\
Calorific Value $(\mathrm{kkal} / \mathrm{kg}$, ar) & 4700 \\
Moisture (\%, abd) & 14.68 \\
Ash Content (\%, abd) & 5.3 \\
Volatile Matter (\%, abd) & 40.58 \\
Fixed Carbon $(\%$, abd) & 39.45 \\
\hline Source: $P A B$ Laboratory $P T, B u k i t$ Asam
\end{tabular}

Source: PAB Laboratory PT. Bukit Asam

The ultimate test of coal content is needed to determine the character and composition of the coal, physically, chemically, and fuel properties of the coal that will be used in the gasification process. Proximate analysis of the MT 47 coal type shows the content of carbon, hydrogen, sulfur, nitrogen, and oxygen on coal. This sampling was carried out in the Coal Transport Handling Unit (PAB) laboratory of PT. Bukit Asam as shown in Table 3.

Table 3. Analysis Ultimate Batubara MT 47

\begin{tabular}{lc}
\multicolumn{2}{c}{ Table 3. Analysis Ultimate Batubara MT 47} \\
\hline \multicolumn{2}{c}{ Analysis Ultimate Batubara MT 47 } \\
\hline Seam & A1 \\
Calorific Value (kkal/kg, ar) & 4700 \\
Carbon (\%adb) & 60.66 \\
Hydrogen (\%adb) & 4.39 \\
Nitrogen (\%adb) & 0.69 \\
Sulfur (\%adb) & 1.03 \\
Oxygen (\%adb) & 13.26 \\
Other & 13.97 \\
\hline Source: PAB Laboratory PT. Bukit Asam
\end{tabular}

Based on the coal proximate analysis results in Table 3, the type of coal can be determined using the Coal Base Conversion Table (ASTDM D385, 2005, America Society for Testing and Materials). This classification is based on the rank of the coal or based on the degree of its metamorphism or changes during the coalification process (ranging from lignite to anthracite). The data on fixed carbon (dmmf), volatile matter (dmmf), and calorific value in Btu/lb are needed on the basis of mmmf (moist, mmf) to determine the rank of coal [20]. For lignite type coal which belongs to the Lignite coal group with a moist calorific value below 8,300 Btu/lb, namely: Lignite A (8300-6300) and Lignite B/ Brown Coal $(<6300$ [20]. Based on the results of the coal proximate analysis in Table 3, coal samples from MT47 obtained a Volatile Matter (dmmf) value of $40.58 \%$, a Fixed Carbon value (dmmf) of $39.45 \%$, and a Calorific Value (mmmf) of $4700 \mathrm{kcal} / \mathrm{kg}$.

\subsection{Underground Coal Gasification Product Test Results}

\subsubsection{Effect of Temperature and Pressure on Underground Coal Gasification Testing Process on} Syngas Produced

The test was carried out using two different samples, namely, In-Situ Type Lignite Coal samples and Fractured Type Lignite Coal samples taken from the MT 47 and Al 51 sampling locations, with oxygen 
injection of $3 \mathrm{~L} /$ minute as the gasification agent

The samples of coal type in-situ were $1.85 \mathrm{~kg}$ weight at the beginning of the test. In the sample test, in the UCG prototype, the gasification process was given the same oxygen injection with the fracture type, namely $3 \mathrm{~L} /$ minute. The part of the column that is colored blue is the time of taking test data, with the time recorded in the 30th minute, the recorded pressure of 1.13 Psia, and the combustion chamber temperature of $1230{ }^{\circ} \mathrm{C}$ where the test of the coal sample, the results were perfectly lit. The weight of the coal sample after the testing process on the UCG prototype for 120 minutes is $1.3 \mathrm{~kg}$. As already explained, the indication of the output gas, syngas, produced during the UCG prototype process, is marked by a flame at the end of the fuel test tube. The gas bag used to accommodate the output gas, syngas, and then the gas is analyzed in the laboratory to determine the gas composition.

Based on the gasification process data using the UCG prototype that has been obtained, a comparison chart can be made between the fracture-type coal sample and the in-situ type coal sample.

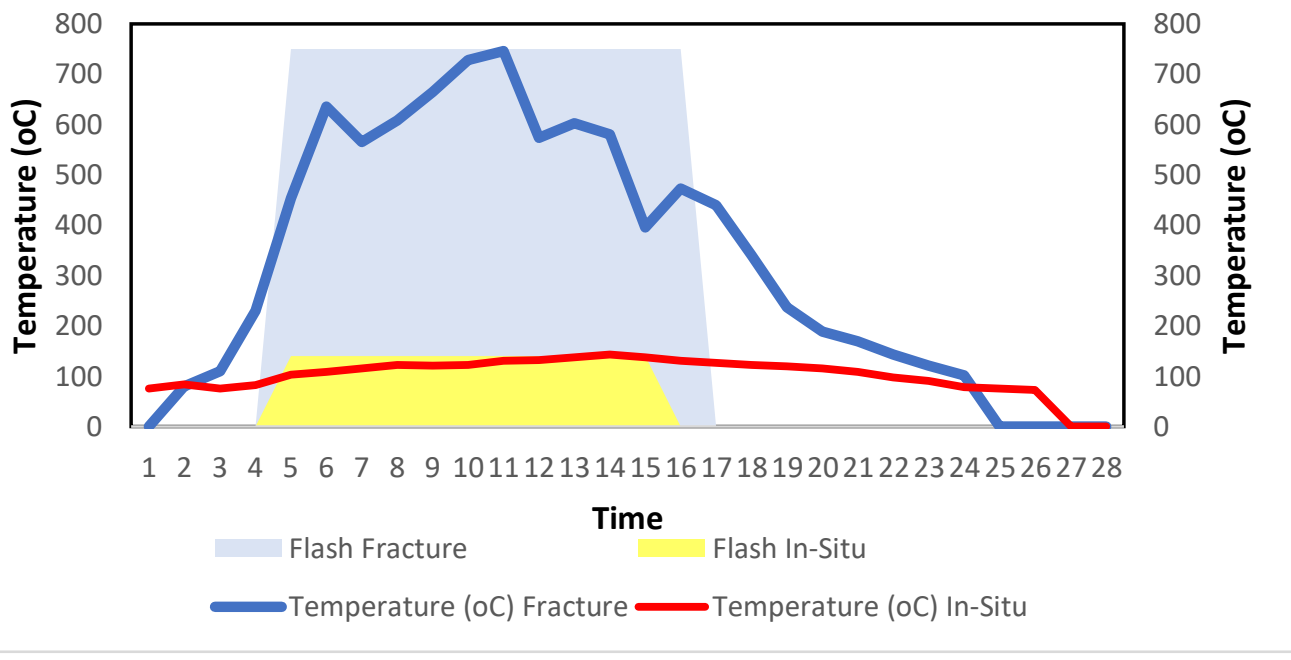

Figure 6. Effect of temperature on gasification process of Lignite MT47 coal sample in-situ type and fracture type

Based on the gasification test data with the UCG prototype that has been obtained, a graph of the relationship between temperature $\left({ }^{0} \mathrm{C}\right)$ to the type of each type of coal can be made. The fracture type has a higher temperature than the in-situ type during the gasification process with the UCG prototype. In the burn test, the condition of the pipe end successfully ignited the fracture type experiencing the lowest temperature of $396{ }^{\circ} \mathrm{C}$ during the test time at 55 minutes and the highest temperature at $746{ }^{\circ} \mathrm{C}$ during the test time at 35 minutes. The type of fracture shown in Figure 6 has the lowest temperature at minute 5 at $75{ }^{\circ} \mathrm{C}$ and the highest temperature at $132{ }^{\circ} \mathrm{C}$ at 50 minutes.

In the measurement of the combustion chamber test temperature for gasification, for samples of fracture type coal and in-situ type, a flame starts to appear at the end of the burn test pipe until it no longer lights up, for 60 minutes for fracture type coal and 50 minutes for coal type in-situ. Furthermore, the pressure changes recorded during the test from fractured and in-situ coal samples can be seen in Figure 7 . In the gasification process using the UCG prototype on fractured and in-situ coal samples, there is a pressure difference during the gasification process between fracture type and in-situ type gasification. Figure 7 shows an increase in pressure when the test data for the fuel test is recorded to be lit at the end of the pipe when the gate valve is opened. The highest pressure in the fracture sample was measured at 4.01 Psi at the 35 th minute and the lowest pressure at 2.13 Psi at minute 55. Then in the in-situ coal sample, the highest pressure was 1.16 Psi at the 50th minute even when the burn test was on, and the lowest pressure was 0.98 at the 5 th minute. 


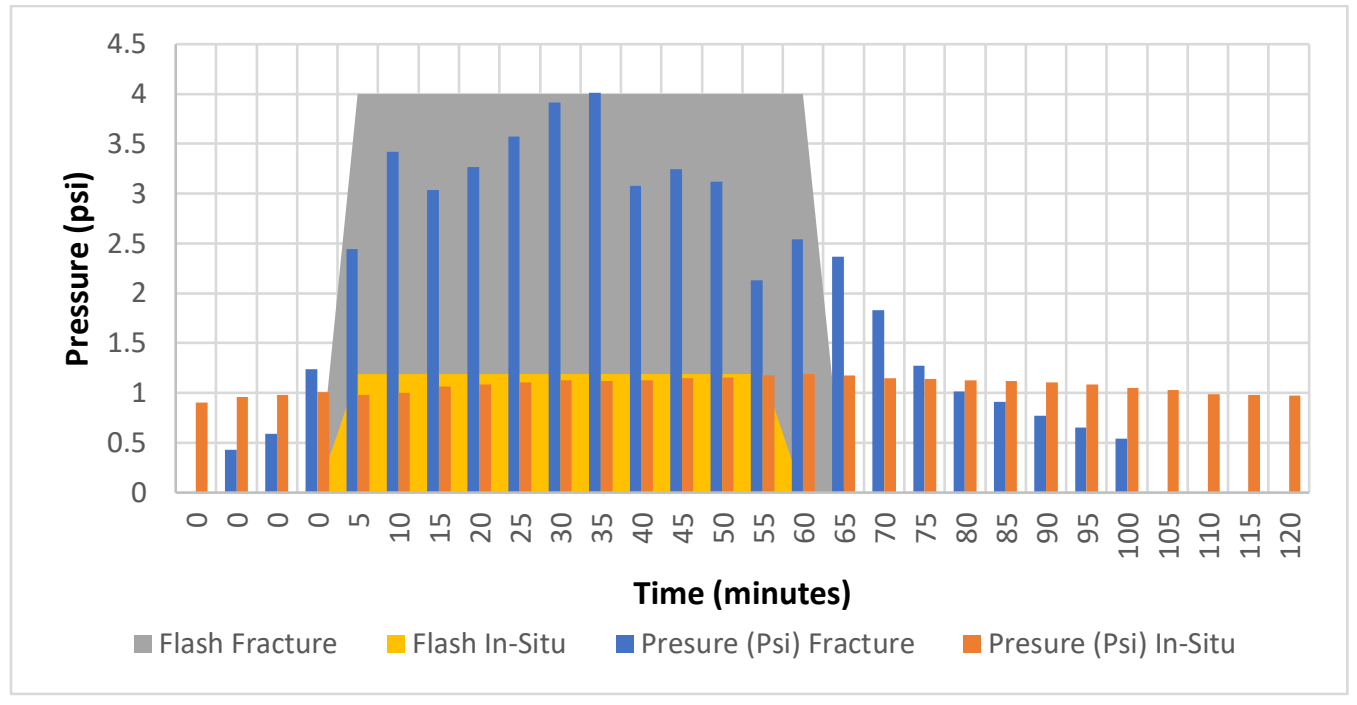

Figure 7. Effect of Pressure on the gasification process of Lignite MT47 coal samples in-situ type and fracture type

Table 4. Average and difference between UCG Gasification Process Temperature and Pressure

\begin{tabular}{ccc} 
Coal Sample Type & Temperature $\left({ }^{0} \mathrm{C}\right)$ & Pressure (Psi) \\
\hline Fracture & 399.39 & 2.15 \\
In-Situ & 105.11 & 1.07 \\
Difference & $\mathbf{2 9 4 . 2 4}$ & $\mathbf{1 . 0 8}$
\end{tabular}

Table 4 shows the differences in average temperature and average pressure in the gasification process for coal samples at $294.245^{\circ} \mathrm{C}$ and 1.08 Psi.

\subsubsection{Syngas Underground Coal Gasification Composition}

The test was carried out using two different samples: the fracture type lignite coal sample and the insitu type lignite coal sample. Based on the analysis that has been carried out, the syngas composition obtained is in Table 5.

Table 5. UCG Syngas Composition

\begin{tabular}{ccccccc}
\hline & & & \multicolumn{3}{c}{ Parameters of Result Analysis } \\
\cline { 4 - 7 } No. & Sample MT47 & $\begin{array}{c}\text { Sampling } \\
\text { Temperature }\end{array}$ & $\begin{array}{c}\mathbf{O}_{2} \\
\mathbf{\%}\end{array}$ & $\begin{array}{c}\mathbf{C O}_{2} \\
\mathbf{\%}\end{array}$ & $\begin{array}{c}\mathbf{C H}_{4} \\
\mathbf{\%}\end{array}$ & $\begin{array}{c}\mathbf{H}_{2} \mathbf{S} \\
(\mathbf{p p m})\end{array}$ \\
\hline 1. & Fracture & $608{ }^{\mathbf{0}} \mathrm{C}$ & 19.43 & 50.46 & 0.24 & 0 \\
2. & In-Situ & $123^{\circ} \mathrm{C}$ & 4.94 & 52.19 & 1.13 & 0 \\
\hline
\end{tabular}

The fracture-type lignite test coal sample is an MT47 coal sample, with Test No.1 sampling carried out at a temperature of $608{ }^{\circ} \mathrm{C}$ and sampling Test No. 2 at a temperature of $123{ }^{\circ} \mathrm{C}$.

Tests carried out on fracture-type lignite coal found a $\mathrm{CH}_{4}$ gas concentration of $0.24 \%$, which is relatively low compared to the In-Situ type lignite coal sample, with a $\mathrm{CH}_{4}$ gas concentration of $1.13 \%$. Based on the theoretical literature on coal rank differences, lignite coal should produce $\mathrm{CH}_{4}$ gas between $1 \%$ - 5\%. This test resulted in fractured type lignite coal, which is relatively small from this value because the distribution of the gasification agent, namely $\mathrm{O}_{2}$ gas, is evenly distributed throughout the temperature sample at the time of gas sampling $\left(608{ }^{\circ} \mathrm{C}\right)$. In addition, the fracture-type coal samples were physically in the form of fragments and the methane content in the coal samples began to disappear (a little). There is a $\mathrm{CH} 4$ value of $1.13 \%$ in the In-Situ Type sample, which is assessed following the theory. This indicates the In-Situ Type is capable of producing higher $\mathrm{CH}_{4}$ gas than the Fracture Type. In both samples, it was found that the $\mathrm{CO}_{2}$ gas content was more significant than the existing theory, which should be in the range of $20 \%-30 \%$. The CO2 concentration was $50.46 \%$ in the fracture sample, and the In-Situ type sample was $52.19 \%$. This is due to complete combustion. In the fracture sample, from $2 \mathrm{~kg}$, there is still $0.55 \mathrm{~kg}$ remaining. While in the In- 
Situ sample of $1.85 \mathrm{~kg}$, there is still $1.3 \mathrm{~kg}$ left. This condition is possible because the coal has not burned completely due to the short testing time. Then the temperature measured in the combustion chamber of the In-situ type sample is lower than the temperature of the fracture-type sample combustion chamber. The InSitu type in the combustion process with lower temperature and pressure can produce $\mathrm{CH}_{4}$ gas. The $\mathrm{O}_{2}$ content was measured with a value of $19.43 \%$ for the Fracture Type sample and the $\mathrm{O}_{2}$ content of $4.94 \%$ in the In-Situ type sample. The concentration of $\mathrm{O}_{2}$ gas products is lower in the In-Situ Type, which means that combustion occurs completely compared to the Fracture Type. Then the $\mathrm{H}_{2} \mathrm{~S}$ content was not found in the gas measurement results from the gasification test for lignite coal samples, both in the Fracture Type and In-Situ Type. Because according to the theory, lignite coal has a little sulfur content.

\section{CONCLUSION}

Based on the research done, it can be concluded that there are 3 gas products from the Underground Coal Gasification test, namely $\mathrm{CH}_{4}$ gas, $\mathrm{CO}_{2}$ gas and $\mathrm{O}_{2}$ gas, which are syngas from coal gasification. The largest gas concentration is the concentration of $\mathrm{CO}_{2}$ gas in the In-Situ type sample of 52.19\%. These results indicate that the tests carried out on the In-Situ Type Coal Sample Test, as an example of gasification, are conditioned by the coal lump sample, which is still like the original, namely below the ground surface has perfect combustion conditions with an indication of the concentration of $\mathrm{O}_{2}$ gas as a gasifying agent. Injected measured at $4.94 \%$, and high $\mathrm{CO}_{2}$ gas was at an average value of $52.19 \%$. The $\mathrm{CH}_{4}$ gas concentration of $1.13 \%$ was produced in the In-Situ type sample with the gasification test process conditions in a low temperature state and a low-pressure value compared to the fracture type sample gasification test process.

From the gasification test of lignite coal samples, the fracture type has a higher temperature in the combustion chamber than the in-situ type coal, with the residual weight of the fracture type after the gasification test being less than the in-situ type residual weight after the combustion test. The gasification test conditions at the fracture type can be said to be in the condition that most of the samples burn out faster than the In-Situ Type. This is because there are gaps between the physical shape of the fracture-type coal sample, making it easier for gasification agent gas, namely oxygen, to be distributed throughout the shape of the fractured coal sample.

\section{ACKNOWLEDGEMENTS}

The authors would like to express profound gratitude to PT. Bukit Asam Tbk for providing the research location and Politeknik Negeri Sriwijaya supporting this research.

\section{REFERENCES}

[1] R. Ploetz, R. Rusdianasari, E. Eviliana, "Renewable Energy: Advantages and Disadvantages," Proceeding Forum in Research, Science, and Technology (FIRST), 2016.

[2] Fitriana, "Outlook Energi Indonesia. Inisiatif Pengembangan Teknologi Energi Bersih", Badan Pengkajian dan Penerapan Teknologi Pusat, Teknologi dan Sumber Daya Energi dan Industri Kimia, Jakarta. 2017.

[3] K. Kostur, M. Laciah, and M. Durdan, "Some Influences of Underground Coal Gasification on the Environment", Sustainability Vol. 10(5), May 2018

[4] D. Doucet, G. Perkins, A. Ulbrich, and ED Toit, "Production of Power using Underground Coal Gasification", Energy Sources, part A: Recovery, Utilization, and Environmental Effect, vol. 38(24), pp. 3653-3660, 2016.

[5] M. Gur and ED Canbaz, "Analysis of Syngas Production and Reaction Zones in Hydrogen Oriented Undeground Coal Gasification", Fuel, Vol. 269, June 2020.

[6] S.B. Javed, A.A. Uppa, A.I. Bhatti, and R. Samar, "Prediction and Parametric Analysis of Cavity Growth for the Underground Coal Gasification Project Thar”, Energy, Vol. 172, pp. 1277-1290, April 2019.

[7] Rusdianasari, S. Arita, E. Ibrahim, and Ngudiantoro, "Reduction of Metal Contents in Coal Stockpile Wastewater using Electrocoagulation", Applied Mechanics and Materials Vol. 391 (2013) pp 29-33

[8] P. Pei, S. Korom, K. Ling, and J. Nasah, "Cost Comparison og Syngas production from Natural Gas Convertion and Underground Coal Gasification”, Mitigation and Adaption Strategies for Global Change, Vol. 21, pp. 629-643, 2016.

[9] Rusdianasari, Y Bow, RAN Moulita. Temperature Effect on the Biodiesel Quality from Waste Cooking Oil by Induction Heating, Journal of Physics: Conf. Series 1450 012003. 2020.

[10] G. Perkin, ED Toit, G Cochrane, and G. Bollaert, "Overview of Underground Coal Gasification Operations at Chinchlilla, Australia”, Energy Sources, part A: Recovery, Utilization, and Environmental Effect, vol. 38(24), pp. 3639-3646, 2016.

[11] Y. Bicer and I. Dincer, "Energy and Exergy Analyses of an Integrated Underground Coal Gasification with SOFC Fuel Cell System for Multigeneration including Hydrogen Production", International Journal of Hydrogen Energy, Vol. 40(39), pp. 13323-13337, October 2015.

[12] G. X. Wang, Z.T. Wang, B. Feng, V. Rudolph, and J.L. Jiao, "Semi-industrial Tests on Enhanced Underground Coal Gasification at Zhong-Liang-Shan Coal Mine", Asia-Pasific Journal of Chemical Engineering, Vol. 4(5), pp. 771-779, October 2009. 
[13] Rusdianasari, A. Taqwa, and Y. Bow, "Treatment of Coal Stockpile Wastewater by Electrocoagulation Using Aluminum Electrodes", Advanced Materials Research Vol. 896 (2014) pp 145-148.

[14] W. Huang, Z. Wang, F. Duan, and L. Xin, "Effect of Oxygen and Steam on gasification and Power Generation in Industrial tests of Underground Coal gasification, Fuel, Vol. 289, April 2021.

[15] Rusdianasari, S. Arita, E. Ibrahim, and Ngudiantoro, "Evaluation on Environmental Effect of Coal Stockpile in Muara Telang, Banyuasin, Indonesia", Journal of Physic Conference Series, 423, 2013.

[16] Rusdianasari, "Pemetaan Kualitas Udara di Lingkungan Stockpile Batubara", Prosiding Seminar Nasional in Research, Science, and Technology (FIRST), 2015.

[17] N. Rachmadona, Y Bow, and A Aswan, "Design of Induction Heating for Coal Liquefaction", Proceeding Forum in Research, Science, and Technology (FIRST), 2016.

[18] A. Syaris, Rusdianasari, M. Yerizam, and MS. Yusi, "Characterization of Thermal Activated Fly Ash Adsorbant by Studying the Effect of Temperature", Proceedings of the 4th Forum in Research, Science, and Technology (FIRSTT1-T2-2020), 2021.

[19] Rusdianasari, "Model Pengelolaan Lingkungan Stockpile Batubara", Disertasi, Pascasarjana Universitas Sriwijaya, 2014.

[20] Rusdianasari, S. Arita, E. Ibrahim, and Ngudiantoro, "Characteristic of Coal Stocpile in Lowland and the effect to Environment", Springer Series in Materials Science, Volume 204 in Recent Trends in Physics of material Science and Technology, 2015.

[21] Y Bow, T Dewi, A Taqwa, Rusdianasari, Zulkarnain, "Power Transistor 2N3055 as a Solar Cell Device," International Conference on Electrical Engineering and Computer Science (ICECOS), IEEE, 2018.

[22] A. Kurniawan, A. Taqwa, Y. Bow, "PLC Application as an Automatic Transfer Switch for on-grid PV System; Case Study Jakabaring Solar Power Plant Palembang,” J. Phys.: Conf. Ser. 1167 012026, 2019.

[23] S Widodo, A Taqwa and R Rusdianasari, "Solar panels output optimization using Phase Change Material (PCM) and heatsink applied in open-pit mining," IOP Conf. Series: Materials Science and Engineering 1073 (2021) 012041, 2021.

[24] Mirdiansyah, A. Taqwa, Y. Bow. "Monitoring Depth of Discharge of a Valve Regulated Lead Acid Battery in a Standalone PV System," Proceedings of the 4th Forum in Research, Science, and Technology (FIRST-T1-T22020), 2021

[25] Y. Bow, A. Syakdani, M. Taufik, and Rusdianasari, "Effect of Drying Ariflow Rate on $\mathrm{H}_{2} \mathrm{O}$ Mass Evaporated on Banana Chips Drying using Photovoltaic Solar Panel”, J. Phys.: Conf. Ser. 1500 012015, 2020.

[26] N. Pasaribu, Rusdianasari, and A. Syarif, "Efficiency of 9Kwp Sun Tracking Photovoltaic in Palembang, Indonesia", IOP Conf. Ser.: Earth Environ. Sci. 347 012129, 2019.

[27] H. Wibowo, Y. Bow, and CR. Sitompul, "Performance Comparison Analysis of Fixed and Solar-Tracker Installed Panel at PV System", IOP Conf. Ser.: Earth Environ. Sci. 709 012003, 2021.

[28] Y. Bow, L. Kalsum, A. Hasan, A. Husaini and Rusdianasari, "The Purification of Biogas with Monoethanolamine (MEA) Solution Based on Biogas Flow Rate,"Proceedings of the 4th Forum in Research, Science, and Technology (FIRST-T1-T2-2020), vol. 7, pp. 12-17, 2021.

[29] Rusdianasari, A. Syarif, M. Yerizam, M. S. Yusi, L. Kalsum, and Y. Bow, "Effect of Catalysts on the Quality of Biodiesel from Waste Cooking Oil by Induction Heating,” J. Phys. Conf. Ser., vol. 1500, no. 1, 2020, doi: $10.1088 / 1742-6596 / 1500 / 1 / 012052$.

[30] A. Garmana, F. Arifin, and Rusdianasari, "CFD Analysis for Combination Savonius and Darrieus Turbine with Differences in the Number of Savonius Turbine Blades", 2021 International Conference on Artificial Intelligence and Mechatronics System (AIMS), IEEE, 2021. 


\section{BIOGRAPHIES OF AUTHORS}

Julismi, was born in Sungai Dareh, July 29, 1972. Completed Diploma III in the Design
Engineering Department at the Polytechnic for Manufacturing, Bandung, West Java, Indonesia,
and completed his bachelor's degree in Electrical Engineering at Universitas Palembang,
continued his education in the Applied Masters Program (S-2) at the Department of Renewable
Energy Engineering Politeknik Negeri Sriwijaya Palembang. Currently, the author works as
President Director of PT Satria Bahana Sarana (PT Bukit Asam Group). The author resides in
Tanah Putih Township Bukit Asam Tanjung Enim,Muara Enim, South Sumatra, Indonesia, at
Jalan Pinus No. 8.

